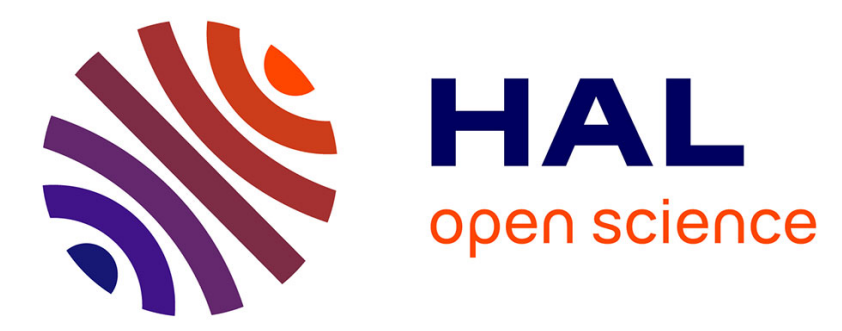

\title{
Pressure effects on the solubility and crystal growth of $\alpha$-quartz
}

F. Lafon, G. Demazeau

\section{To cite this version:}

F. Lafon, G. Demazeau. Pressure effects on the solubility and crystal growth of $\alpha$-quartz. Journal de Physique IV Proceedings, 1994, 04 (C2), pp.C2-177-C2-182. 10.1051/.jp4:1994221 • jpa-00252489

\section{HAL Id: jpa-00252489 https://hal.science/jpa-00252489}

Submitted on 1 Jan 1994

HAL is a multi-disciplinary open access archive for the deposit and dissemination of scientific research documents, whether they are published or not. The documents may come from teaching and research institutions in France or abroad, or from public or private research centers.
L'archive ouverte pluridisciplinaire HAL, est destinée au dépôt et à la diffusion de documents scientifiques de niveau recherche, publiés ou non, émanant des établissements d'enseignement et de recherche français ou étrangers, des laboratoires publics ou privés. 


\title{
Pressure effects on the solubility and crystal growth of $\alpha$-quartz
}

\author{
F. LAFON and G. DEMAZEAU
}

Laboratoire de Chimie du Solide du CNRS et Interface Hautes Pressions, LCS-CNRS-ENSCPB, Université Bordeaux I, 33405 Talence cedex, France

\begin{abstract}
Industrial $\alpha$-quartz growth mainly refers to hydrothermal reactions with dissolution stage mass transport and crystallization at the interface between aqueous solution/seed. Experimental investigations on $\alpha$-quartz dissolution with high pressure in different aqueous solutions $\left(\mathrm{NaOH}-1 \mathrm{M}, \mathrm{Na}_{2} \mathrm{CO}_{3}-1 \mathrm{M}\right)$ have underlined that : pressure parameter increases the solubility limit (s 1$)$ of $\alpha$-quartz for each investigated solution. In a high pressure range ( $200 \leq \mathrm{P} \leq$ $350 \mathrm{MPa}), \mathrm{Na}_{2} \mathrm{CO}_{3}(1 \mathrm{M})$ seems a better solvent than $\mathrm{NaOH}(1 \mathrm{M})$. Experimental studies on $\alpha-$ quartz growth rate versus pressure in both aqueous solutions $\mathrm{NaOH}(1 \mathrm{M})$ and $\mathrm{Na}_{2} \mathrm{CO}_{3}(1 \mathrm{M})$ indicates the existence of a maximum for the kinetics of crystallization. In the case of $\mathrm{Na}_{2} \mathrm{CO}_{3}(1 \mathrm{M})$ a more complex variation of the growth rate is observed [1].

The use of pressure beyond $200 \mathrm{MPa}$ could open new developments in $\alpha$-quartz crystal-growth through :

(i) a better knowledge of conventional solvents $\left(\mathrm{NaOH}\right.$ and $\left.\mathrm{Na}_{2} \mathrm{CO}_{3}\right)$ in such a pressure domain,

(ii) the investigation of new solvents more appropriate to reduce the concentration of chemical defects,
\end{abstract}

\section{1/ INTRODUCTION}

A considerable number of studies on the solubility of $\alpha$-quartz crystals in water at elevated temperatures and pressures exist up to now [2,3]. However no determinations of $\alpha$-quartz solubility limit in aqueous solutions such as $\mathrm{NaOH}(1 \mathrm{M}), \mathrm{Na}_{2} \mathrm{CO}_{3}(1 \mathrm{M})$ using high pressures conditions from $200 \mathrm{MPa}$ to $350 \mathrm{MPa}$ at temperature of $400^{\circ} \mathrm{C}$ have been reported.

Because of the importance of pressure parameter on the crystal growth process during the hydrothermal preparation of $\alpha$-quartz, the evaluation of pressure effect on the dissolution in different aqueous solutions was an important step.

As high frequency applications of $\alpha$-quartz requires sheets with small thickness of the same order of size than the defects (such as inclusions, etch pits and dislocations, Fig. 1), so pressure parameter can promote new solvents for hydrothermal growth, especially for reducing their concentration. 

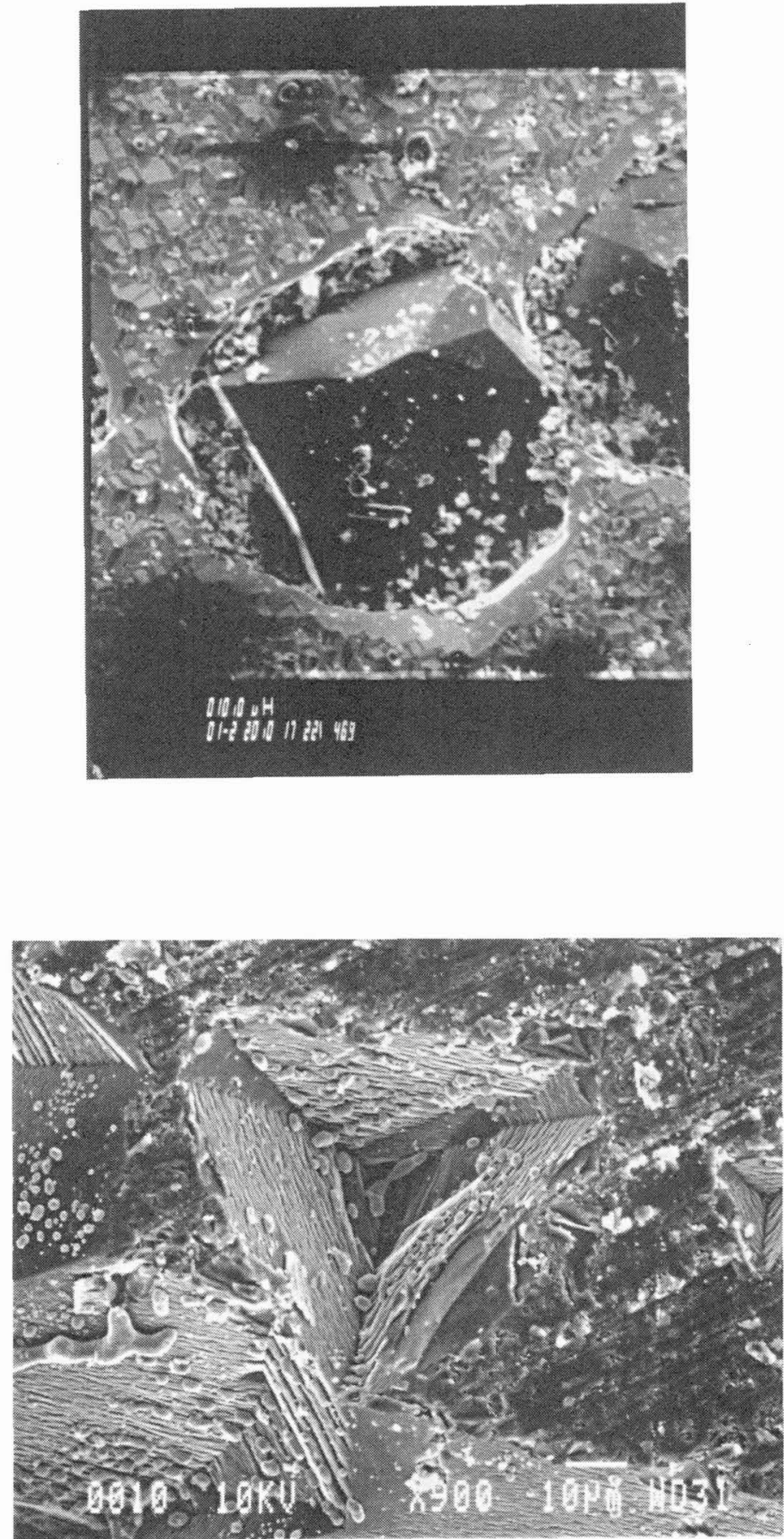

Figure 1 : Inclusion phase in the top and etch-picts in the bottom seen by SEM. 


\section{2/ EXPERIMENTAL METHODOLOGY}

Solubility limits have been calculated for each run in term of $\mathrm{g} / \mathrm{l}$ of aqueous solution. The mass of Madagascar $\alpha$-quartz generally used is close to $3 \mathrm{~g}$ with a typical size of 1-2 $\mathrm{mm}$ for each grain in order to maintain approximately constant the specific area. Experiments have been carried out in high pressure vessels built with refractory alloys with a cone/cone closing system (Fig. 2).

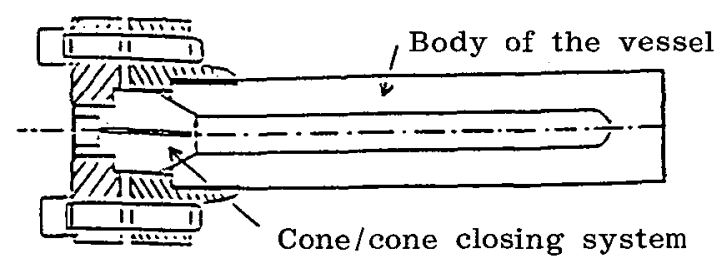

Figure 2 - Diagrammatic section of the high pressure vessel used for dissolution cycles

The reaction vessel, completely filled with the solvent, contains the nutrient placed in a gold tube in order to reduce the inner contamination.

The heating used a conventional furnace. Time (192 hours) is enough, in order to insure that the observed solubility value corresponds to the solubility limit ( $\left.\mathrm{s}_{1}\right)$ in the selected $\mathrm{P}, \mathrm{T}$ conditions. At the end of the run, the pressure vessel is quenched, the $\alpha$-quartz removed, dried and reweighed. The mass loss $(\Delta \mathrm{m})$ is calculated and coupled with the volume of aqueous solution in the vessel (V) leading to the solubility limit value $\mathrm{s}_{1}=\Delta \mathrm{m} / \mathrm{V}$ correlated to the involved temperature and pressure. To insure the validity of such experiments at least two tests for each $(P, T, t)$ set were carried out.

\section{3/ EXPERIMENTAL RESULTS}

3.1/ Pressure effect on $\alpha$-quartz dissolution at $\mathrm{T} \approx 400^{\circ} \mathrm{C}$ for different solvents $\mathrm{NaOH}(1 \mathrm{M})$ and $\mathrm{Na}_{2} \mathrm{CO}_{3}(1 \mathrm{M})$

\section{$\underline{\text { 3.1.1/ } \alpha \text {-quartz solubility limit using an aqueous solution } \mathrm{NaOH}(1 \mathrm{M})}$}

The solubility limit values have been plotted versus pressure at $400^{\circ} \mathrm{C}$ (Fig. 3). 


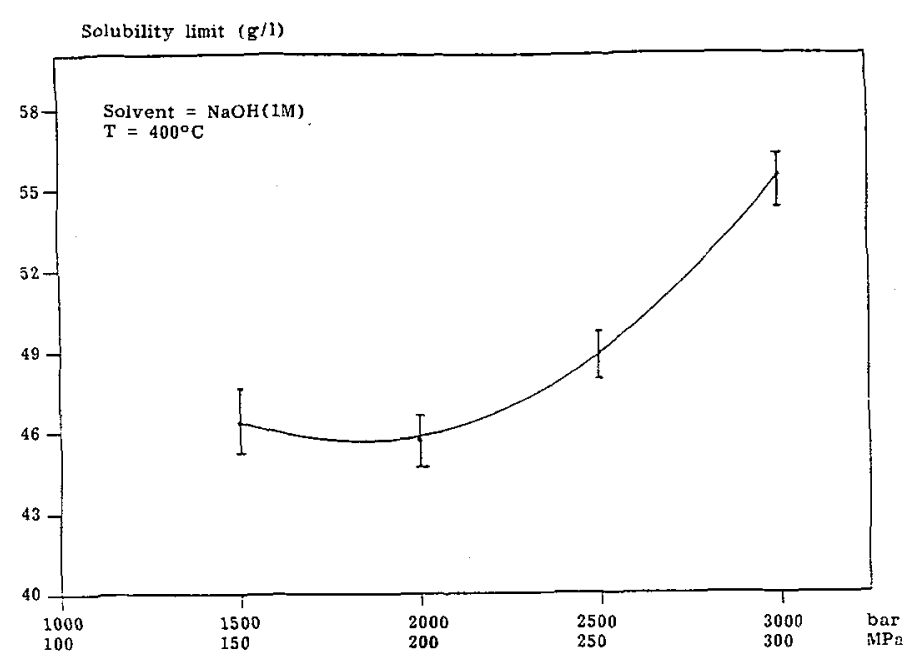

Figure 3 - Quartz solubility limit in $\mathrm{NaOH}(1 \mathrm{M})$ vs. pressure at constant temperature $\left(400^{\circ} \mathrm{C}\right)$

At pressure below $200 \mathrm{MPa}$, there is a pressure domain in which the solubility limit (s $)$ of $\alpha$ quartz seems to fall with a minimum (at approximately $200 \mathrm{MPa}$ ) with a value close to $45 \mathrm{~g} / \mathrm{l}$. At pressure above this, $\mathrm{s} 1$ increases in $\mathrm{NaOH}(1 \mathrm{M})$ up to $300 \mathrm{MPa}$ (last studied experimental pressure). At this upper limit $\mathrm{s}_{1}$ is close to $51.25 \mathrm{~g} / \mathrm{l}$.

\section{$\underline{3.1 .2 / \alpha-q u a r t z}$ solubility limit in $\mathrm{Na}_{2} \underline{\mathrm{CO}_{3}} \underline{3}(1 \mathrm{M})$ aqueous solution}

The pressure effect on $\alpha$-quartz dissolution at constant temperature $400^{\circ} \mathrm{C} \mathrm{s}=\mathrm{f}(\mathrm{P})$ is given on figure 4 .

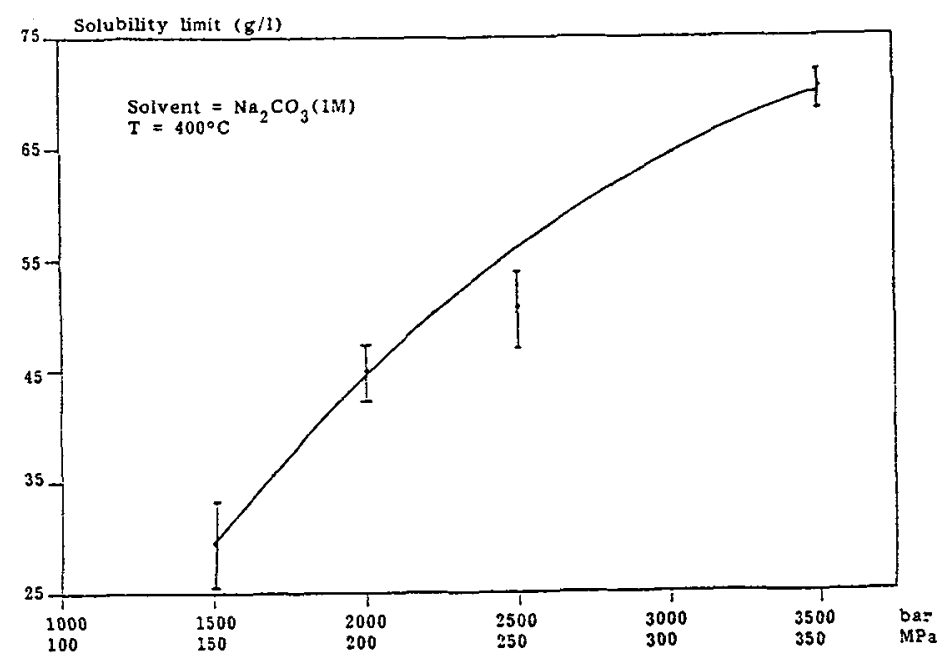

Figure 4 - Quartz solubility limit in $\mathrm{Na}_{2} \mathrm{CO}_{3}(1 \mathrm{M})$

vs. pressure in constant temperature $\left(400^{\circ} \mathrm{C}\right)$ 
3.2/ Comparison of the solubility limit (s!) of $\alpha$-quartz between $\mathrm{NaOH}(1 \mathrm{M})$ and $\mathrm{Na}_{2} \mathrm{CO}_{3}(1 \mathrm{M})$ aqueous solutions vs. pressure at a constant temperature $\left(400^{\circ} \mathrm{C}\right)$

At $400^{\circ} \mathrm{C}$, the solubility limit for $\mathrm{P} \geq 200 \mathrm{MPa}$ is higher in $\mathrm{Na}_{2} \mathrm{CO}_{3}(1 \mathrm{M})$ than in $\mathrm{NaOH}(1 \mathrm{M})$ (Fig. 5).

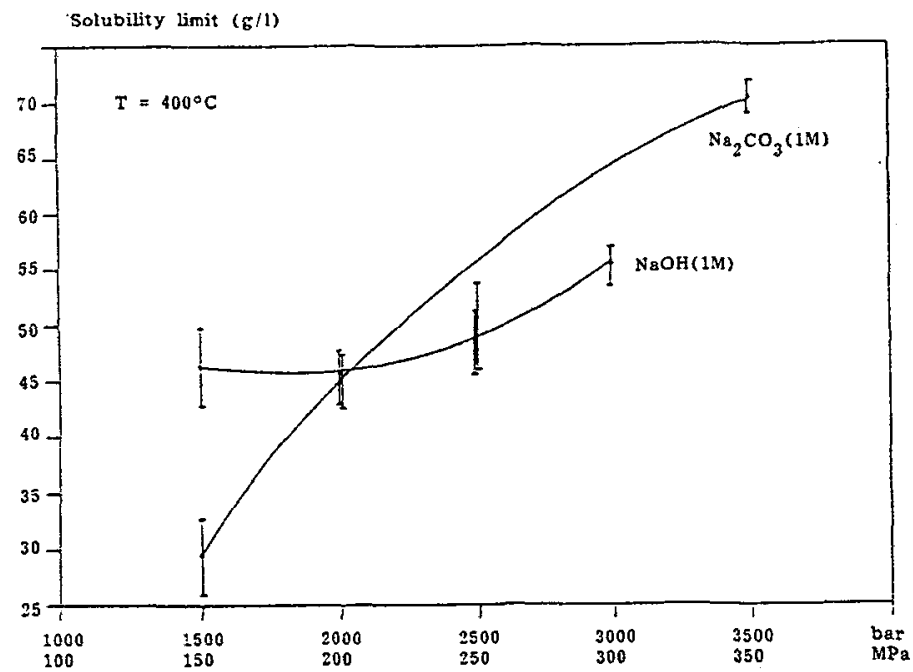

Figure 5 - Solubility limit comparison between $\mathrm{NaOH}(1 \mathrm{M})$ and $\mathrm{Na}_{2} \mathrm{CO}_{3}(1 \mathrm{M})$ vs. pressure at $400^{\circ} \mathrm{C}$.

Through these experiments sodium carbonate appears to be a better solvent than sodium hydroxide in high pressure domain for a temperature close to $400^{\circ} \mathrm{C}$. This result could be reported in the hydrothermal $\alpha$-quartz growth applications. $\mathrm{Na}_{2} \mathrm{CO}_{3}(1 \mathrm{M})$ solution could be a more appropriate solvent for setting up a high pressure process if the resulting quality of the synthetic quartz is compatible with high frequency applications.

\section{3 - Enthalpy of dissolution of $\alpha-q u a r t z$ at constant temperature $\left(400^{\circ} \mathrm{C}\right)$}

The data concerning the solubility limit in $\mathrm{NaOH}(1 \mathrm{M})$ and in $\mathrm{Na}_{2} \mathrm{CO}_{3}(1 \mathrm{M})$ aqueous solutions determined by the weight loss method for different pressure values (150-350 MPa) are plotted as $\ln \left(s_{1}\right)=f(1 / p)$ (Fig. 6). The corresponding curve is linear in the pressure domain (150-350 MPa) 
for $\mathrm{Na}_{2} \mathrm{CO}_{3}(\mathrm{IM})$ and presents a small deviation to the linearity for $\mathrm{NaOH}(1 \mathrm{M})$ in the domain (200-350MPa).

From the slope of the curves (Fig. 6), the enthalpy values of $\alpha$-quartz dissolution at constant temperature $\left(400^{\circ} \mathrm{C}\right)$ can be calculated versus the nature of the solvent.

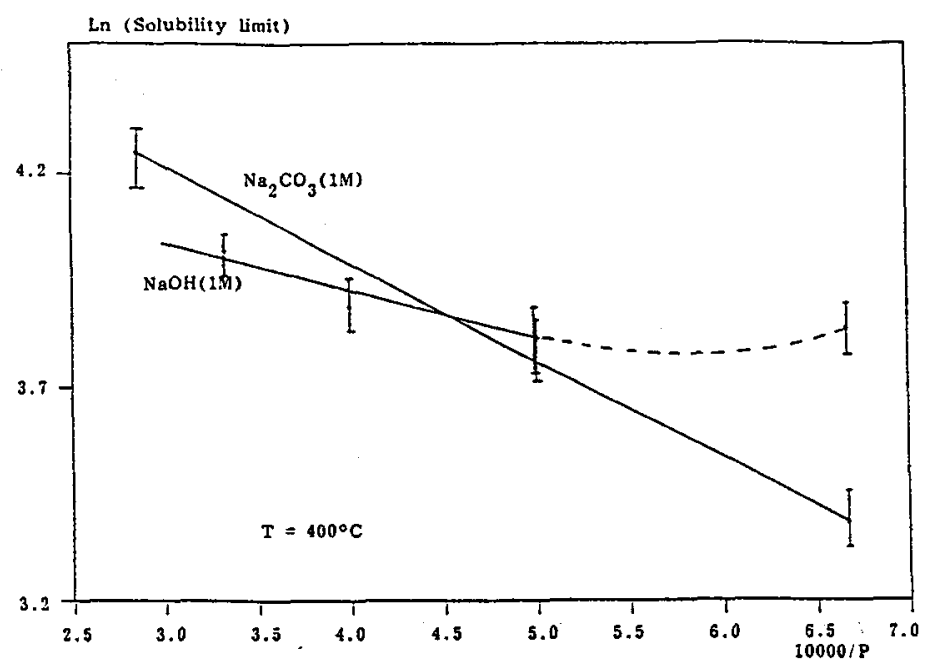

Figure 6 - Logarithm of the solubility $\left(\mathrm{s}_{1}\right)$ in $\mathrm{NaOH}(1 \mathrm{M})$ and in $\mathrm{Na}_{2} \mathrm{CO}_{3}(1 \mathrm{M})$ vs. 1/P

$\Delta \mathrm{H}_{\mathrm{T}}=2395 \pm 5 \mathrm{cal} / \mathrm{mole}$ for $\mathrm{NaOH}(1 \mathrm{M}) ; 200 \leq \mathrm{P} \leq 350 \mathrm{MPa}$

$\Delta \mathrm{H}_{\mathrm{T}}=4110 \pm 2 \mathrm{cal} /$ mole for $\mathrm{Na}_{2} \mathrm{CO}_{3}(1 \mathrm{M}) ; 150 \leq \mathrm{P} \leq 350 \mathrm{MPa}$

\section{References}

[1] Lafon F. Demazeau G., "Pressure effect on the dissolution of $\alpha$-quartz in different aqueous solutions", High Pressure Research (in press).

[2] Kennedy George C., Econ. Geol. 45 (1950), 629-653.

[3] Laudise R.A., Contribuion from the bell Tel. Leb., 81, 562-564, 81. 